\title{
Syntheses of simple TADDOL-like phosphite, phosphonite and phosphonate chiral ligands
}

\author{
Jesica P. Perotti, ${ }^{a}$ Raquel M. Cravero, ${ }^{\text {biliana E. Luna, }}$ Ricardo J. A. Grau, ${ }^{\text {a }}$ and \\ Santiago E. Vaillard ${ }^{\mathrm{a} *}$ \\ ${ }^{a}$ Instituto de Desarrollo Tecnológico para la Industria Química (INTEC). Centro Científico- \\ Tecnológico Santa Fe.CONICET-UNL. Ruta Nacional 168. Km 1. Paraje El Pozo, 3000, \\ Santa Fe, Argentina \\ ${ }^{b}$ Instituto de Química de Rosario (IQUIR). Centro Científico-Tecnológico Rosario. Suipacha \\ 531, S2000LRK, Rosario, Argentina \\ E-mail: svaillard@mail.intec.unl.edu.ar
}

Dedicated to the memories of Prof. Ricardo J. A. Grau and Prof. M. Inés Cabrera

\begin{abstract}
New simple phosphite, phosphonite and phosphonate chiral ligands derived from DIMPTH $(\mathrm{OH})_{2}$ and rigid bis-DIMPTH $(\mathrm{OH})_{2}$ were prepared with moderate to good yields (35-86\%) from readily available starting materials. The syntheses of the new chiral ligands required the use of $\mathrm{Et}_{3} \mathrm{~N}$ as base, since the use of more nucleophilic DIMPTH $(\mathrm{OH})_{2}$ alkoxides precluded the formation of the ligands. Representative ligands of each family were evaluated in the asymmetric copper catalyzed addition reaction of $\mathrm{Et}_{2} \mathrm{Zn}$ to 2-cyclohexenone, 2-cyclopentenone and acyclic $\alpha$ $\beta$-unsaturated ketones. Noteworthy, the less hindered and simple phosphonate ligand derived from DIMPTH $(\mathrm{OH})_{2}$ induced enantioselection in the more difficult asymmetric reactions.
\end{abstract}

Keywords: Chiral ligands, phosphite, phosphonite, phosphonate, TADDOL, phosphorus ligands

\section{Introduction}

Natural occurring carbohydrates are abundant and readily available starting materials that have been widely used as molecular scaffolds for the construction of chiral ligands for asymmetric catalysis. ${ }^{1}$ On the other hand, chiral trivalent phosphorus derivatives are extremely important ligands in transition-metal mediated asymmetric catalytic reactions, such as asymmetric Michael additions, asymmetric allylic substitutions and asymmetric hydrogenations among other important transformations. ${ }^{2}$ Although some well established trends can be followed for every type of reaction, it is nowadays clear that the chiral ligand employed in the asymmetric 
transformation is one of the most important issues to be considered in order of achieving appropriate asymmetric induction. In this regard, TADDOL $\left(\alpha, \alpha, \alpha^{\prime}, \alpha^{\prime}\right.$-tetraphenyl-1,3dioxolane-4,5-dimethanol) and its derivatives are a well known family of compounds that have been used as chiral ligands in several relevant stereoselective transformations. ${ }^{3}$ TADDOL phosphites and phosphonites are interesting chiral ligands that have successfully been used in the copper catalyzed enantioselective conjugate addition of $\mathrm{Et}_{2} \mathrm{Zn}$ to different acceptors. Among the several different TADDOL phosphorus ligands that have been prepared and evaluated in asymmetric catalysis, compounds $\mathbf{1}$ and $\mathbf{2}$ proved to be useful in the asymmetric conjugate addition of $\mathrm{Et}_{2} \mathrm{Zn}$ to cyclic enones, chalcones and nitroalkenes. ${ }^{4-6}$

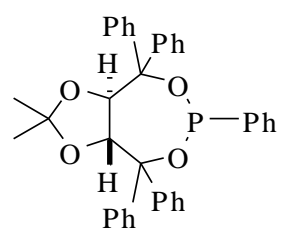

1

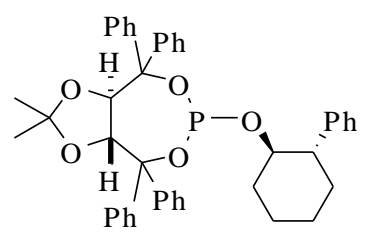

2

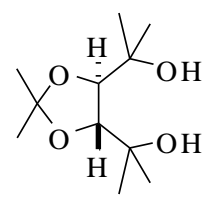

3

TADDOL on which the aryl moieties have been replaced by alkyl groups have received, however, little attention compared with the $\alpha, \alpha^{\prime}$-tetraryl compounds. In particular, $\operatorname{DIMPTH}(\mathrm{OH})_{2} 3$ ( $\alpha, \alpha, \alpha^{\prime}, \alpha^{\prime}$-tetramethyl-1,3-dioxolane-4,5-dimethanol), which is a TADDOL analogue bearing four methyl groups in the $\alpha, \alpha^{\prime}$-positions, has scarcely been studied. Although $\operatorname{DIMPTH}(\mathrm{OH})_{2}$ is a known compound, phosphorus ligands derived from $\mathbf{3}$ have only recently been obtained and evaluated in asymmetric catalysis. ${ }^{7}$ It has been shown that aryl-phosphonites derivatives of $\mathrm{DIMPTH}(\mathrm{OH})_{2}$ are effective monodentate ligands for the asymmetric hydrogenative aldol coupling of vinyl ketones. Noteworthy, this is the only report on the synthesis of phosphorus (III) derivatives of DIMPTH $(\mathrm{OH})_{2}$ and it was demonstrated that, by a careful selection of the ligands substructures, high chemical and optical yields can be achieved. In this work it was also indicated that increasing the steric hindrance in the carbinol moiety can result in decreased reactivity. ${ }^{7}$

A distinctive reaction outcome was observed in the chlorination reactions of TADDOL and $\operatorname{DIMPTH}(\mathrm{OH})_{2}$ with $\mathrm{SOCl}_{2}{ }^{8}$ Depending on the reaction temperature, TADDOL reacts with excess of $\mathrm{SOCl}_{2}$ affording the corresponding dichlorinated product and cyclic sulphite, that is formed by intramolecular substitution. ${ }^{8}$ The formation of the di-halogenated product is favored at higher temperatures, while cyclic sulphite is formed as the only product at $-40^{\circ} \mathrm{C}$. On the other hand, the reaction of $\operatorname{DIMPTH}(\mathrm{OH})_{2}$ with $\mathrm{SOCl}_{2}$ affords the cyclic sulphite as the only product, regardless of the temperature used. ${ }^{8 \mathrm{~b}}$ An unexpected rearrangement was also observed in the reaction of DIMPTH $(\mathrm{OH})_{2}$ with $\mathrm{TiCl}_{4}{ }^{9}$

In the last years it has been shown that rigid bis-TADDOL derivatives can successfully be used in photochemical and organocatalytic enantioselective transformations. ${ }^{10}$ Despite the fact that NMR studies on the host-guest behavior of bis-TADDOL compounds have been performed, and given the utility of these derivatives as organocatalysts, phosphorus chiral ligands derived 
from bis-TADDOL have not yet been prepared. ${ }^{11,12}$ Furthermore, it has been suggested that the spatially favorable arrangement on this family of compounds could positively influence the asymmetric induction ability.

The recent successful use of DIMPTH $(\mathrm{OH})_{2}$ phosphites in asymmetric catalysis and the limited available information on the chemistry of $\operatorname{DIMPTH}(\mathrm{OH})_{2}$ and bis-DIMPTH(OH $)_{2}$ induced us to obtain some simple DIMPTH $(\mathrm{OH})_{2}$ and rigid bis-DIMPTH $(\mathrm{OH})_{2}$ phophite and phosphonite chiral ligands that could find application in metal-catalyzed enantioselective 1,4addition reactions. $^{13,14}$

\section{Results and Discussion}

TADDOL phosphites and phosphonites are interesting chiral ligands that have been used mainly in the copper catalyzed enantioselective conjugate addition of $\mathrm{Et}_{2} \mathrm{Zn}$ to cyclic enones, enones, nitroalkenes and chalcones. Although $\operatorname{DIMPTH}(\mathrm{OH})_{2}$ is a known compound, its use in enantioselective synthesis has only scarcely been studied.

Starting from L-(+)-tartaric acid, DIMPTH $(\mathrm{OH})_{2} \mathbf{3}$ was easily obtained in good yield following known methodology. ${ }^{15}$ The new bis-DIMPTH $(\mathrm{OH})_{2} \mathbf{5}$ derivative was obtained in high yield $(96 \%)$ by the reaction of bis-acetonide 4 with $\mathrm{MeMgCl}$ (equation 1). ${ }^{11}$
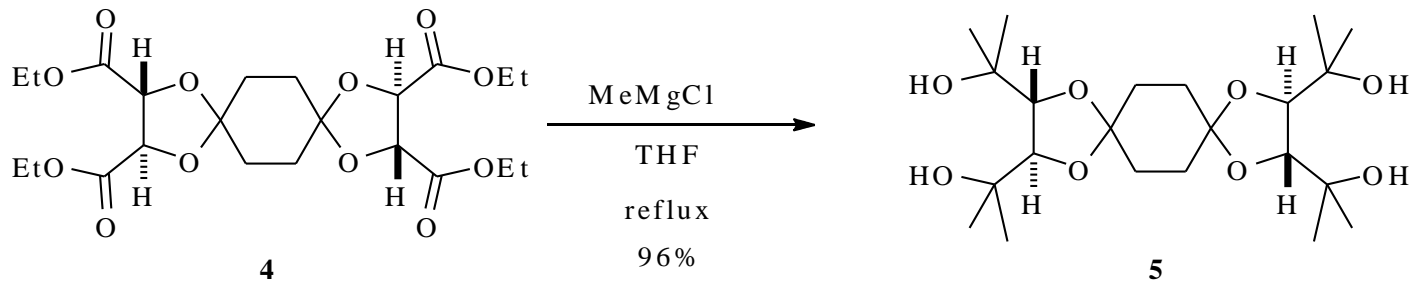

The increased steric hindrance on the $\alpha, \alpha^{\prime}$-positions of $\operatorname{DIMPTH}(\mathrm{OH})_{2}$, along with the distinctive reaction outcome of the DIMPTH $(\mathrm{OH})_{2}$ skeleton, early suggested that the syntheses of the ligands might not be so simple as suggested by the initial screening of the DIMPTH(OH $)_{2}$ structure. $^{5 b}$

The most widely used method for the synthesis of cyclic phosphites involves the initial formation of the $(\mathrm{RO})_{2} \mathrm{P}-\mathrm{Cl}$ intermediate 6 in the presence of $\mathrm{Et}_{3} \mathrm{~N}$ to trap the formed $\mathrm{HCl}$,

followed by the addition of the alcohol (equation 2). ${ }^{16}$ With this simple method, phosphites 7 and $\mathbf{8}$ were obtained in 58 and $86 \%$ yield respectively. 


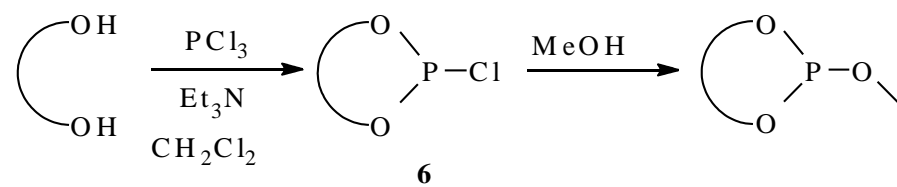

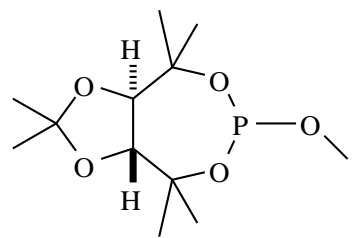

$7(58 \%)$

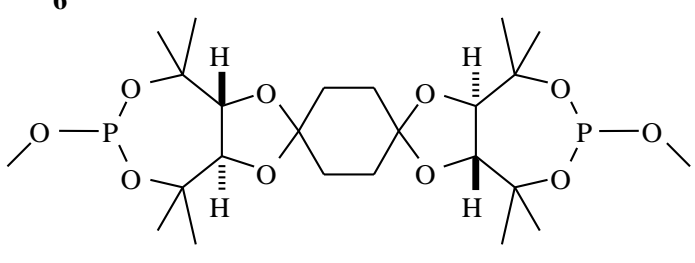

$8(86 \%)$

It was reported that the reaction of the TADDOL bis-lithium alkoxide, obtained by reaction of TADDOL and $n$-BuLi, with $\mathrm{PCl}_{3}$ is an alternative useful method for the preparation of the $(\mathrm{RO})_{2} \mathrm{P}-\mathrm{Cl}$ intermediate that avoids the formation of the ammonium salt. This method failed with compounds $\mathbf{3}$ and $\mathbf{5}$ and, consequently, ligands $\mathbf{7}$ and $\mathbf{8}$ could not be isolated from the complex reaction mixtures following this approach.

The synthesis of cyclic phosphonites chiral ligands derived from TADDOL is usually accomplished by the reaction of the bis-lithium alkoxide of TADDOL with commercially available $\mathrm{Cl}_{2} \mathrm{PR}$ (R:alkyl, aryl) or by the reaction of the $(\mathrm{RO})_{2} \mathrm{P}-\mathrm{Cl}$ intermediate with organolithium reagents. ${ }^{17}$ The first and classical method involving the generation of bis-lithium alkoxide of $\operatorname{DIMPTH}(\mathrm{OH})_{2}$ afforded a complex reaction mixture from which the cyclic phosphonites could not be isolated. After several attempts, chiral ligands 9 and $\mathbf{1 0}$ were obtained in moderate yield by the reaction of 3 and 5 with $\mathrm{Cl}_{2} \mathrm{PPh}$ in the presence of $\mathrm{Et}_{3} \mathrm{~N}$ as base (equation 3). Chiral phosphonate $\mathbf{9}$ is probably formed from the parent phosphonite by oxidation during column chromatography purification.

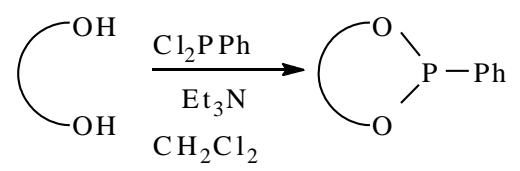

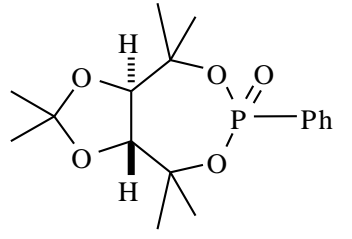

$9(35 \%)$

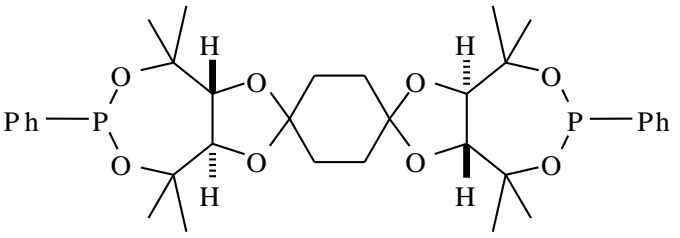

$10(46 \%)$

To gain information into the potential of the ligands, these compounds were tested in the copper-mediated enantioselective conjugate addition reaction. In this regard, the copper catalyzed conjugate addition of $\mathrm{Et}_{2} \mathrm{Zn}$ to 2-cyclohexenone, (equation 4), is nowadays one of most classical carbon-carbon bond-forming reactions used to evaluate new phosphorus chiral ligands. The effect of the solvent, the temperature and the copper source for this reaction were all studied 
in detail. ${ }^{18}$ The optimization of the reaction conditions were performed using ligand $\mathbf{1 0}$ and $\mathrm{Cu}(\mathrm{OTf})_{2}, \mathrm{Cu}(\mathrm{OAc})_{2}, \mathrm{CuI}$, and $\mathrm{CuCN}$ as copper sources (Table 1).

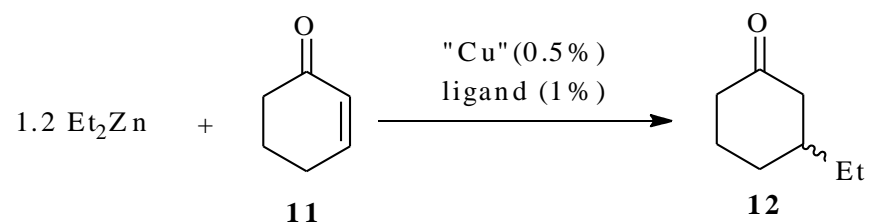

As shown in table 1, reactions proceed with complete conversion although low ee\% values were obtained in all cases, regardless of the solvent and copper source. In toluene all reactions proceeded to completion at reasonable reactions times (entries 1-4 in Table 1), in agreement with the data reported in the literature. With the exception of $\mathrm{CuCN}$, the reactions required up to $66 \mathrm{~h}$ to be completed in $\mathrm{CH}_{2} \mathrm{Cl}_{2}$ (entries 5-8 in Table 1). In diehyl ether the reactions carried out with $\mathrm{CuI}$ and $\mathrm{CuCN}$ were slow, while the reactions with $\mathrm{Cu}(\mathrm{OTf})_{2}$ and $\mathrm{Cu}(\mathrm{OAc})_{2}$ were concluded in $23 \mathrm{~h}$ (entries 8-12 in Table 1). Accordingly, toluene as solvent and $\mathrm{Cu}(\mathrm{OTf})_{2}$ as the copper source were used for the evaluation of the others ligands (entry 1 in Table 1).

Table 1. Optimization of the reaction conditions for the copper catalyzed 1,4-addition of $\mathrm{Et}_{2} \mathrm{Zn}$ to 2-cyclohexenone with ligand $\mathbf{1 0}$

\begin{tabular}{ccccc}
\hline Entry & Conditions & Solvent & $\mathrm{Cu}$ source & Yield \% (ee \% $)^{\mathrm{a}, \mathrm{b}}$ \\
\hline 1 & $-30{ }^{\circ} \mathrm{C}$ to $-20{ }^{\circ} \mathrm{C}, 17 \mathrm{~h}$ & toluene & $\mathrm{Cu}(\mathrm{OTf})_{2}$ & $84(5)$ \\
2 & $-30{ }^{\circ} \mathrm{C}$ to $-20{ }^{\circ} \mathrm{C}, 17 \mathrm{~h}$ & toluene & $\mathrm{Cu}(\mathrm{OAc})_{2}$ & $50(0)$ \\
3 & $-30{ }^{\circ} \mathrm{C}$ to $-20{ }^{\circ} \mathrm{C}, 23 \mathrm{~h}$; then $0{ }^{\circ} \mathrm{C}, 0.5$ & toluene & $\mathrm{CuI}$ & $41(3)$ \\
4 & $-30{ }^{\circ} \mathrm{C}$ to $-20{ }^{\circ} \mathrm{C}, 25 \mathrm{~h}$, then rt $64 \mathrm{~h}$ & toluene & $\mathrm{CuCN}^{\mathrm{c}}$ & $45(0)$ \\
5 & $-30{ }^{\circ} \mathrm{C}$ to $-20{ }^{\circ} \mathrm{C}, 23 \mathrm{~h}$, then rt $66 \mathrm{~h}$ & $\mathrm{CH}_{2} \mathrm{Cl}_{2}$ & $\mathrm{Cu}(\mathrm{OTf})_{2}{ }^{\mathrm{d}}$ & $76(0)$ \\
6 & $-30{ }^{\circ} \mathrm{C}$ to $-20{ }^{\circ} \mathrm{C}, 23 \mathrm{~h}$, then rt $66 \mathrm{~h}$ & $\mathrm{CH}_{2} \mathrm{Cl}_{2}$ & $\mathrm{Cu}(\mathrm{OAc})_{2}{ }^{\mathrm{e}}$ & $64(0)$ \\
7 & $-30{ }^{\circ} \mathrm{C}$ to $-20{ }^{\circ} \mathrm{C}, 23 \mathrm{~h}$, then rt $66 \mathrm{~h}$ & $\mathrm{CH}_{2} \mathrm{Cl}_{2}$ & $\mathrm{CuI}$ & $43(2)$ \\
8 & $-30{ }^{\circ} \mathrm{C}$ to $-20{ }^{\circ} \mathrm{C}, 23 \mathrm{~h}$ & $\mathrm{CH}_{2} \mathrm{Cl}_{2}$ & $\mathrm{CuCN}$ & $71(2)$ \\
9 & $-30{ }^{\circ} \mathrm{C}$ to $-20{ }^{\circ} \mathrm{C}, 23 \mathrm{~h}$ & $\mathrm{Et}_{2} \mathrm{O}$ & $\mathrm{Cu}(\mathrm{OTf})_{2}$ & $75(7)$ \\
10 & $-30{ }^{\circ} \mathrm{C}$ to $-20{ }^{\circ} \mathrm{C}, 23 \mathrm{~h}$ & $\mathrm{Et}_{2} \mathrm{O}$ & $\mathrm{Cu}(\mathrm{OAc})_{2}$ & $71(2)$ \\
11 & $-30{ }^{\circ} \mathrm{C}$ to $-20{ }^{\circ} \mathrm{C}, 23 \mathrm{~h}$, then rt $64 \mathrm{~h}$ & $\mathrm{Et}_{2} \mathrm{O}$ & $\mathrm{CuI}^{\mathrm{f}}$ & $85(2)$ \\
12 & $-30{ }^{\circ} \mathrm{C}$ to $-20{ }^{\circ} \mathrm{C}, 23 \mathrm{~h}$, then rt $64 \mathrm{~h}$ & $\mathrm{Et}_{2} \mathrm{O}$ & $\mathrm{CuCN}$ & $92(6)$ \\
\hline
\end{tabular}

${ }^{a}$ Isolated product yield (complete reactions thin layer chromatography). ${ }^{\mathrm{b}} \mathrm{ee} \%$ were measured by gas chromatography with an Astec Chiralex G-TA column $40 \mathrm{~m}$ x $0.25 \mathrm{~mm}$ x $0.12 \mu \mathrm{m}$ film thick, carrier gas: helium. Absolute stereochemistry was not determined. In all cases the major enantiomers were the same (shorter retention time, see Experimental Section). ${ }^{\mathrm{c}}$ At $24 \mathrm{~h}$ of reaction, additional $1.5 \mathrm{~mol} \%$ of $\mathrm{CuCN}$ was added. ${ }^{\mathrm{d}}$ At $42 \mathrm{~h}$ of reaction, additional $0.8 \mathrm{~mol} \%$ of $\mathrm{Cu}(\mathrm{OTf})_{2}$ was added. ${ }^{\mathrm{e}}$ At $42 \mathrm{~h}$ of reaction, additional $0.5 \mathrm{~mol} \%$ of $\mathrm{Cu}(\mathrm{OAc})_{2}$ was added. ${ }^{\mathrm{f}}$ At $24 \mathrm{~h}$ 
of reaction, additional $10 \mathrm{~mol} \%$ of $\mathrm{CuI}$ was added. ${ }^{\mathrm{g}}$ At $24 \mathrm{~h}$ of reaction, additional $10 \mathrm{~mol} \%$ of $\mathrm{CuCN}$ was added.

As we previously indicated, in the optimized conditions ligand $\mathbf{1 0}$ afforded the addition product with high yield but with low ee\% (entry 1 in Table 2). Similar results were obtained with phosphite ligand 8 and phosphonate ligand 9 (entries 2 an 3 in Table 2). Phosphite ligand 7 proved to be less reactive, and moderate yield and low ee\% were obtained using $\mathrm{Cu}(\mathrm{OTf})_{2}(20 \mathrm{~h})$ or $\mathrm{Cu}(\mathrm{OAc})_{2}(1.5 \mathrm{~h})$ as the copper source (entries 4 and 5 in Table 2).

As expected, the more demanding and reactive 2-cyclopentenone 13 (equation 5) afforded high chemical yields of the conjugate addition product 14 with low ee\% values (entries 6-9 in Table 2).

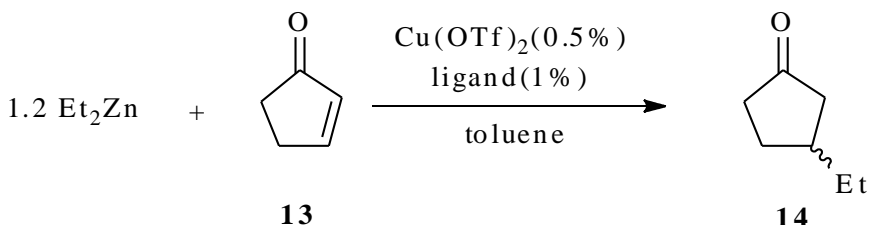

Alkyl substituted acyclic enones, such as $(E)-4$-phenylbut-3-en-2-one 15a and $(E)-4-(4-$ methoxyphenyl)but-3-en-2-one $\mathbf{1 5 b}$, have been less studied in copper-mediated asymmetric conjugate addition of $\mathrm{Et}_{2} \mathrm{Zn}$ (equation 6). Due to $s$-cys and $s$-trans interconversion this type of substrates are more demanding and they usually require different ligands than those that proved to be successful with cyclic enones.

When TADDOL phosphonite ligand $\mathbf{1}$ was evaluated in the copper-catalyzed enantioselective conjugate addition of $\mathrm{Et}_{2} \mathrm{Zn}$ to $(E)$-4-phenylbut-3-en-2-one, the racemic addition product was obtained after $24 \mathrm{~h}$ of reaction at $-5{ }^{\circ} \mathrm{C}$ (8\% yield). Rigid phosphonite $\mathbf{1 0}$ and phosphite 8 and DIMPTH $(\mathrm{OH})_{2}$ phosphonate 9 and phosphite 7 proved to be more reactive than the reported TADDOL phosphonite and good yields of the addition product were obtained in short reaction times (entries 10-13 in Table 2). In clear contrast with the data reported in the literature, ${ }^{5 a}$ noticeable asymmetric induction was observed with simple ligands $\mathbf{8 , 9}$ and $\mathbf{1 0}$.

Deactivated (E)-4-(4-methoxyphenyl)but-3-en-2-one 15b was less reactive than $(E)$-4phenylbut-3-en-2-one 15a, and prolonged reaction times and increased temperatures were required to obtain addition product 16b with acceptable yields (entries 14-24 in Table 2). As expected, lower ee $\%$ values and higher yields were obtained when the temperature was increased (entries 15, 18 and 24 in Table 2). Noteworthy, enantiomeric excess of up to 47 ee $\%$ were obtained with the new and simple phosphonate 9 within reasonable reaction times using diethyl ether as solvent (entries 19 and 20 in Table 2). 
Table 2. Evaluation of ligands 7, 8, 9 and $\mathbf{1 0}$ with different acceptors

\begin{tabular}{|c|c|c|c|c|}
\hline Entry & Enone & Ligand & Conditions & Product yield $\%(\text { ee } \%)^{\mathrm{a}, \mathrm{b}}$ \\
\hline 1 & 11 & 10 & $-30^{\circ} \mathrm{C}, 17 \mathrm{~h}$ & $1284^{\mathrm{c}}(5)$ \\
\hline 2 & 11 & 8 & $-30{ }^{\circ} \mathrm{C}, 21 \mathrm{~h}$ & $12100(0)$ \\
\hline 3 & 11 & 9 & $-30{ }^{\circ} \mathrm{C}, 22 \mathrm{~h}$ & $12100(10)$ \\
\hline 4 & 11 & 7 & $-30{ }^{\circ} \mathrm{C}$ to $-20{ }^{\circ} \mathrm{C}, 20 \mathrm{~h}$ & $1252(5)$ \\
\hline $5^{\mathrm{d}}$ & 11 & 7 & $-30{ }^{\circ} \mathrm{C}$ to $-20{ }^{\circ} \mathrm{C}, 1,5 \mathrm{~h}$ & $1247(5)$ \\
\hline 6 & 13 & 10 & $-30{ }^{\circ} \mathrm{C}, 22 \mathrm{~h}$ & $14100(0)$ \\
\hline 7 & 13 & 8 & $-30{ }^{\circ} \mathrm{C}, 22 \mathrm{~h}$ & $14100(4)$ \\
\hline 8 & 13 & 9 & $-30{ }^{\circ} \mathrm{C}, 22 \mathrm{~h}$ & $14100(6)$ \\
\hline 9 & 13 & 7 & $-30{ }^{\circ} \mathrm{C}, 22 \mathrm{~h}$ & $1470(6)$ \\
\hline 10 & $15 \mathbf{a}$ & 10 & $-30{ }^{\circ} \mathrm{C}, 3 \mathrm{~h}$ & 16a $100(38)$ \\
\hline 11 & $15 \mathbf{a}$ & 8 & $-30{ }^{\circ} \mathrm{C}, 3 \mathrm{~h}$ & 16a $100(26)$ \\
\hline 12 & $15 \mathbf{a}$ & 9 & $-30{ }^{\circ} \mathrm{C}, 3 \mathrm{~h}$ & 16a $100(36)$ \\
\hline 13 & $15 \mathbf{a}$ & 7 & $-30{ }^{\circ} \mathrm{C}, 3 \mathrm{~h}$ & 16a $100(0)$ \\
\hline 14 & $15 b$ & 10 & $-30{ }^{\circ} \mathrm{C}, 30 \mathrm{~h}$ & 16b $28(36)$ \\
\hline 15 & $15 b$ & 10 & $-30{ }^{\circ} \mathrm{C}, 30 \mathrm{~h}$, then r. t. $96 \mathrm{~h}$ & 16b 71(20) \\
\hline 16 & $15 b$ & 8 & $-30^{\circ} \mathrm{C}, 30 \mathrm{~h}$ & 16b 20(42) \\
\hline 17 & $15 b$ & 9 & $-30^{\circ} \mathrm{C}, 30 \mathrm{~h}$ & 16b 12(36) \\
\hline 18 & $15 b$ & 9 & $\begin{array}{c}-30{ }^{\circ} \mathrm{C}, 71 \mathrm{~h}, \text { then r. t. } 10 \\
\text { days }\end{array}$ & 16b 62(26) \\
\hline $19^{\mathrm{e}}$ & $15 b$ & 9 & $-30{ }^{\circ} \mathrm{C}, 3,5 \mathrm{~h}$ & 16b 33(47) \\
\hline $20^{\mathrm{e}}$ & $15 b$ & 9 & $-30{ }^{\circ} \mathrm{C}, 72 \mathrm{~h}$ & 16b $46(42)$ \\
\hline $21^{\mathrm{f}}$ & $15 b$ & 9 & $-30^{\circ} \mathrm{C}, 3,5 \mathrm{~h}$ & $\mathbf{1 6 b} 12(0)$ \\
\hline $22^{\mathrm{f}}$ & $15 b$ & 9 & $-30{ }^{\circ} \mathrm{C}, 8$ days & 16b 24(0) \\
\hline 23 & $15 b$ & 7 & $-30{ }^{\circ} \mathrm{C}, 30 \mathrm{~h}$ & 16b 28(36) \\
\hline 24 & $15 b$ & 7 & $-30{ }^{\circ} \mathrm{C}, 71 \mathrm{~h}$, then r. t. $96 \mathrm{~h}$ & 16b 71(20) \\
\hline
\end{tabular}

${ }^{a}$ Yields were determined by gas chromatography by the internal standard method using authentic samples with a HP5 column, $30 \mathrm{~m}$ x $0.32 \mathrm{~mm} \times 0.12 \mu \mathrm{m}$ film thick, carrier gas: nitrogen. ${ }^{\mathrm{b}}$ ee $\%$ were measured by gas chromatography with an Astec Chiraldex G-TA column, $40 \mathrm{~m}$ x $0.25 \mathrm{~mm}$ x $0.12 \mu \mathrm{m}$ film thick, carrier gas: helium. Absolute stereochemistry was not determined. In all cases the major enantiomers (products 12, 14, 16a and 16b) were the same (shorter retention time, see Experimental Section). ${ }^{\mathrm{c}}$ Isolated product yield. ${ }^{\mathrm{d}}$ The copper source: $\mathrm{Cu}(\mathrm{OAc})_{2}{ }^{\mathrm{e}}{ }^{\mathrm{T}}$ The solvent was diethyl ether. ${ }^{\mathrm{f}}$ The solvent was diethyl ether and the copper source was $\mathrm{Cu}(\mathrm{OAc})_{2}$. 


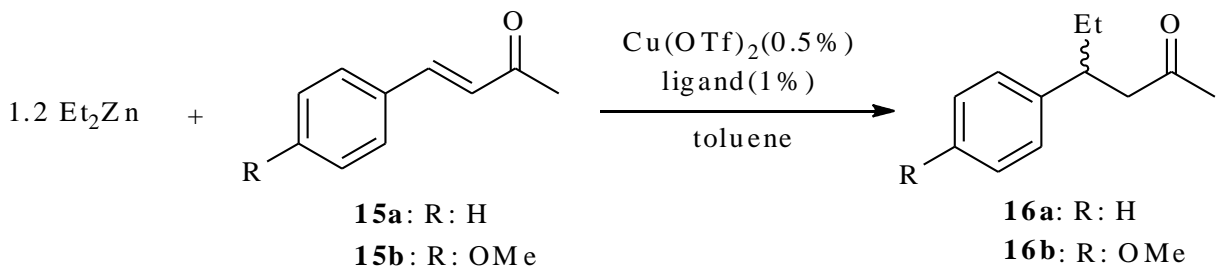

This interesting result suggest that the less hindered and simple phosphonate ligand derived from DIMPTH $(\mathrm{OH})_{2} 9$ might be enough to induce enantioselection in difficult asymmetric reactions.

In summary, in this work four new different phosphates, phosphonites and phosphonates of $\operatorname{DIMPTH}(\mathrm{OH})_{2}$ and bis- DIMPTH $(\mathrm{OH})_{2}$ have been designed and prepared. The chiral ligands were obtained in good to moderate yields. The results obtained in the copper-catalyzed asymmetric addition of $\mathrm{Et}_{2} \mathrm{Zn}$ to cyclic enones indicate that these ligands are not useful in this type of transformation. On the other hand, when the more demanding acyclic enones are used as substrates, acceptable yields of the addition products with enantiomeric excesses of up to 47 ee $\%$ were obtained.

\section{Conclusions}

The chemistry of DIMPTH $(\mathrm{OH})_{2}$, the tetramethyl TADDOL analogue, has scarcely been reported in the literature. Moreover, only few examples of the synthesis and evaluation of phosphorus chiral ligands derived from DIMPTH $(\mathrm{OH})_{2}$ have been informed. In this work we prepared four new cyclic phosphite, phosphonites and phosphonates derived from $\operatorname{DIMPTH}(\mathrm{OH})_{2}$. Furthermore, two chiral ligands derived from rigid bis-DIMPTH $(\mathrm{OH})_{2}$ scaffold were obtained. The synthesis of the chiral ligands is not simple and a specific set of reaction conditions is needed in each case in order to obtain the required ligands with acceptable to high yields (35-86\%). All the methods that involve the formation of $\operatorname{DIMPTH}(\mathrm{OH})_{2}$ alkoxides failed and the reactions were successful only in the presence of $\mathrm{Et}_{3} \mathrm{~N}$ for $\mathrm{HCl}$ trap. The preliminary results obtained in the copper-catalyzed asymmetric addition of $\mathrm{Et}_{2} \mathrm{Zn}$ to $(E)$-4-phenylbut-3-en-2one and (E)-4-(4-methoxyphenyl)but-3-en-2-one suggest that at least one of the ligands may find application in asymmetric catalysis.

\section{Experimental Section}

General. ${ }^{1} \mathrm{H}$ NMR and ${ }^{13} \mathrm{C}$ NMR were performed in $\mathrm{CDCl}_{3}$ on a Bruker AV 300 spectrometer and referenced with the residual solvent signal. ${ }^{31} \mathrm{P}$ NMR spectra were obtained in the same equipment and were referenced to external $\mathrm{H}_{3} \mathrm{PO}_{4}$. Coupling constants $(J)$ are given in Hz. High resolution mass spectra (ESI) were taken on Bruker Daltonics MicroTof at the mass 
spectrometry facility of the Instituto de Química Rosario, Universidad Nacional de RosarioCONICET. Chiral GC analyses were performed in Shimadzu GC-17A gas cromatograph coupled to Shimadzu QP 5000 mass spectrometer using an Astec Chiraldex G-TA column (40 m x 0.25 $\mathrm{mm} \times 0.12 \mu \mathrm{m})$ (carriers gas: helium). Melting points were measured on a Büchi B-540 melting point apparatus. Pre-coated aluminum plates (silica gel, $0.25 \mathrm{~mm}$, UV and iodine detection) were used in TLC analyses and silica gel (200 mesh) was used for flash column chromatography purifications. Solvents for chromatography were purified following standard methods. THF and diethyl ether were distilled under nitrogen atmosphere from sodium benzophenone ketyl inmediately before use. $\mathrm{CH}_{2} \mathrm{Cl}_{2}$ was distilled under nitrogen atmosphere from $\mathrm{P}_{2} \mathrm{O}_{5}$ inmediately before use. Toluene was distilled from sodium chips under inert atmosphere and stored over molecular sieves (4 $\left.\AA^{\AA}\right)$. $\mathrm{Et}_{3} \mathrm{~N}$ was distilled from calcium hydride under inert atmosphere of nitrogen and stored over molecular sieves ( $4 \AA$ ). Methanol was refluxed over $\mathrm{CaSO}_{4}$ and stored over molecular sieves (4 Á). L-(+)-Tartaric acid (Aldrich), 1,4-cyclohexane-dione (Aldrich), $\mathrm{Cl}_{2} \mathrm{PPh}$ (Aldrich), $\mathrm{PCl}_{3}$ (Merck) and $\mathrm{MeMgCl}$ (3 M THF solution, Aldrich), Et ${ }_{2} \mathrm{Zn}$ (1.0 M hexanes solution, Aldrich) and 2-cyclohexenone (Aldrich) were used as received from de suppliers.

$\alpha, \alpha, \alpha^{\prime}, \alpha^{\prime}$-Tetramethyl-1,3-dioxolane-4,5-dimethanol (DIMPTH $(\mathrm{OH})_{2}, 3$ was prepared from diethyl $(2 R, 3 R)-2,3-0$-isopropylidenetartrate following a reported procedure. ${ }^{15}(2 R, 3 R, 10 R, 11 R)$ Tetrakis(ethyl carboxylate)-1,4,9,12-tetraoxadispiro-[4.2.4.2] tetra-decane 4 was prepared from 1,4-cyclohexanedione and diethyl $(2 R, 3 R)-(+)$-tartrate by a known method. ${ }^{11}(E)-4$-Phenylbut-3en-2-one and (E)-4-(4-methoxyphenyl)but-3-en-2-one were obtained as indicated in the literature. $^{23}$

$(2 R, 3 R, 10 R, 11 R)$-Tetrakis(hydroxydimethylmethyl)-1,4,9,12-tetraoxadispiro[4.2.4.2]tetradecane (5). In a flame and vacuum dried $100 \mathrm{~mL}$ two necked round bottomed flask equiped with a reflux condenser, a magnetic stirrer and a rubber septum were added under nitrogen atmosphere THF (30 mL) and $9.2 \mathrm{~mL}$ of $\mathrm{MeMgCl} \mathrm{THF}$ solution (3 M, $27.64 \mathrm{mmol}$ ). The solution was warmed to $50{ }^{\circ} \mathrm{C}$ and a solution of $4(1.5 \mathrm{~g}, 3.07 \mathrm{mmol})$ in $10 \mathrm{~mL}$ of THF was added with a syringe in $10 \mathrm{~min}$ with strong stirring. The reaction mixture was heated at reflux for $5 \mathrm{~h}$ and stirred at room temperature for $18 \mathrm{~h}$. The reaction mixture was cooled in an ice bath and quenched by the slow addition of saturated $\mathrm{NH}_{4} \mathrm{Cl}(30 \mathrm{~mL})$. The crude reaction was extracted with EtOAc $(3 \times 30 \mathrm{~mL})$, the organic phase was dried $\left(\mathrm{MgSO}_{4}\right)$ and the solvent removed at reduced pressure to afford a solid that was purified by column chromatography using hexanes/ EtOAc $(80: 20)$ as elution solvent. Compound 5 was obtained as white solid (1.275 g, 96\%), mp: 139-145 ${ }^{\circ} \mathrm{C} .{ }^{1} \mathrm{H}$ NMR $\left(300 \mathrm{MHz}, \mathrm{CDCl}_{3}\right) \delta: 3.76$ (s, 4H), 2.63 (s, 8H), 1.25 (s, 24H). ${ }^{13} \mathrm{C} \mathrm{NMR}$ $\left(75 \mathrm{MHz}, \mathrm{CDCl}_{3}\right) \delta$ : 107.3, 82.5, 70.6, 33.7, 29.1, 23.0. HRMS (ESI) calcd for $\mathrm{C}_{22} \mathrm{H}_{40} \mathrm{O}_{8} \mathrm{Na}$ $\left([\mathrm{M}+\mathrm{Na}]^{+}\right):$455.2615. Found: 455.2607. 


\section{Synthesis of ligand (7)}

A flame and vacuum dried $10 \mathrm{~mL}$ Schlenk flask equipped with a rubber septum and magnetic stirrer was cooled in an ice bath and $3(70 \mathrm{mg}, 0.32 \mathrm{mmol})$ and $2.0 \mathrm{~mL}$ of $\mathrm{CH}_{2} \mathrm{Cl}_{2}$ were added under inert atmosphere of nitrogen. $\mathrm{Et}_{3} \mathrm{~N}(153 \mu \mathrm{L}, 1.09 \mathrm{mmol})$ was slowly added and the reaction mixture was stirred for $10 \mathrm{~min}$ at $0{ }^{\circ} \mathrm{C}$. The reaction was allowed to reach room temperature and stirred for further $10 \mathrm{~min}$. After cooling again to $0{ }^{\circ} \mathrm{C}$ neat $\mathrm{PCl}_{3}(30 \mu \mathrm{L}, 0.33$ $\mathrm{mmol}$ ) was added and the reaction mixture was stirred at this temperature for $10 \mathrm{~min}$ and then 10 min at room temperature. The Schlenk flask was cooled to $0{ }^{\circ} \mathrm{C}$ and methanol $(28 \mu \mathrm{L}, 0.70$ mmol) was added. The reaction was allowed to reach room temperature and stirred for $22 \mathrm{~h}$. The reaction solvent was removed under vacuum and the crude reaction mixture was directly purified by column chromatography using hexane/ $\mathrm{Et}_{3} \mathrm{~N}(96: 4)$ as elution solvent. Compound 7 was obtained as a viscous oil (52 mg, 58\%). ${ }^{1} \mathrm{H}$ NMR (300 MHz, $\left.\mathrm{CDCl}_{3}\right) \delta: 4.19(\mathrm{~d}, J=9.2,1 \mathrm{H}), 4.09$ (d, $J=9.2,1 \mathrm{H}), 3.53$ (d, J=11.5, 3H), 1.47 (s, 3H), 1.44 (s, 3H), 1.43 (s, 3H), 1.39 (s, 6H), 1.38 $(\mathrm{s}, 3 \mathrm{H}) .{ }^{13} \mathrm{C}$ NMR $\left(75 \mathrm{MHz}, \mathrm{CDCl}_{3}\right) \delta: 109.8,82.3\left(\mathrm{~d}, J^{\mathrm{c}-\mathrm{p}}=14.3\right), 81.5\left(\mathrm{~d}, J^{\mathrm{c}-\mathrm{p}}=4.5\right), 49.4\left(\mathrm{~d}, J^{\mathrm{c}-}\right.$ $\mathrm{p}=12.8), 30.2\left(\mathrm{~d}, J^{\mathrm{c}-\mathrm{p}}=3.5\right), 30.0,27.3\left(\mathrm{~d}, J^{\mathrm{c}-\mathrm{p}}=6.0\right), 22.8,22.1\left(J^{\mathrm{c}-\mathrm{p}}=6.0\right) .{ }^{31} \mathrm{P}$ NMR $(121 \mathrm{MHz}$, $\mathrm{CDCl}_{3}$ ). $\delta$ : $134.01 \mathrm{HRMS}(\mathrm{ESI})$ calcd for $\mathrm{C}_{12} \mathrm{H}_{23} \mathrm{O}_{5} \mathrm{PNa}\left([\mathrm{M}+\mathrm{Na}]^{+}\right)$: 301.1175. Found: 301.1169 .

\section{Synthesis of ligand (8)}

A flame and vacuum dried $5 \mathrm{~mL}$ Schlenk flask equipped with a rubber septum and a magnetic stirrer was cooled in an ice bath and $5(50 \mathrm{mg}, 0.12 \mathrm{mmol})$ and $2.0 \mathrm{~mL}$ of $\mathrm{CH}_{2} \mathrm{Cl}_{2}$ were added under inert atmosphere of nitrogen. $\mathrm{Et}_{3} \mathrm{~N}(110 \mu \mathrm{L}, 0.79 \mathrm{mmol})$ was slowly added and the reaction mixture was stirred for $10 \mathrm{~min}$ at $0^{\circ} \mathrm{C}$. The reaction was allowed to reach room temperature and stirred for further $10 \mathrm{~min}$. After cooling again to $0^{\circ} \mathrm{C}$, neat $\mathrm{PCl}_{3}(21 \mu \mathrm{L}, 0.24$ mmol) was added and the reaction mixture was stirred at this temperature for $10 \mathrm{~min}$ and then 10 min at room temperature. The Schlenk flask was cooled to $0^{\circ} \mathrm{C}$ and methanol $(20 \mu \mathrm{L}, 0.5 \mathrm{mmol})$ was added. The reaction was allowed to reach room temperature and stirred for $22 \mathrm{~h}$. The reaction solvent was removed under vacuum and the crude reaction mixture was directly purified by column chromatography using hexane/Et ${ }_{3} \mathrm{~N}(96: 4)$ as elution solvent. Compound 8 was obtained as a viscous oil $(57 \mathrm{mg}, 86 \%) .{ }^{1} \mathrm{H}$ NMR $\left(300 \mathrm{MHz}, \mathrm{CDCl}_{3}\right) \delta: 4.19$ (d, J=9, 2H), 4.08 $(\mathrm{d}, J=9,2 \mathrm{H}), 3.53(\mathrm{~s}, 3 \mathrm{H}), 3.52(\mathrm{~s}, 3 \mathrm{H}) 1.79(\mathrm{~s}, 8 \mathrm{H}), 1.47(\mathrm{~s}, 6 \mathrm{H}), 1.44(\mathrm{~s}, 6 \mathrm{H}), 1.41(\mathrm{~s}, 6 \mathrm{H}), 1.36$ $(\mathrm{s}, 6 \mathrm{H}) .{ }^{13} \mathrm{C} \mathrm{NMR}\left(75 \mathrm{MHz}, \mathrm{CDCl}_{3}\right) \delta: 109.2,82.0\left(\mathrm{~d}, J^{\mathrm{c}-\mathrm{p}}=13.7\right), 81.2\left(\mathrm{~d}, J^{\mathrm{c}-\mathrm{p}}=4.0\right), 49.6,33.6$ $\left(\mathrm{d}, J^{\mathrm{c}-\mathrm{p}}=6.6\right), 30.2\left(\mathrm{~d}, J^{\mathrm{c}-\mathrm{p}}=4.0\right), 29.7,22.7,22.2\left(\mathrm{~d}, J^{\mathrm{c}-\mathrm{p}}=6.8\right) .{ }^{31} \mathrm{P} \mathrm{NMR}\left(121 \mathrm{MHz}, \mathrm{CDCl}_{3}\right) . \delta$ : 133.62 HRMS (ESI) calcd for $\mathrm{C}_{24} \mathrm{H}_{42} \mathrm{O}_{10} \mathrm{P}_{2} \mathrm{H}\left([\mathrm{M}+\mathrm{H}]^{+}\right)$: 553.2331. Found: 553.2311.

\section{Synthesis of ligand (9)}

A flame and vacuum dried $10 \mathrm{~mL}$ Schlenk flask equipped with a rubber septum and magnetic stirrer was cooled in an ice bath and $3(70 \mathrm{mg}, 0.32 \mathrm{mmol})$ and $2.0 \mathrm{~mL}$ of $\mathrm{CH}_{2} \mathrm{Cl}_{2}$ were added under inert atmosphere of nitrogen. $\mathrm{Et}_{3} \mathrm{~N}(153 \mu \mathrm{L}, 1.09 \mathrm{mmol})$ was slowly added and the reaction mixture was stirred for $10 \mathrm{~min}$ at $0{ }^{\circ} \mathrm{C}$. The reaction was allowed to reach room temperature and stirred for further $10 \mathrm{~min}$. After cooling again to $0{ }^{\circ} \mathrm{C}$ neat $\mathrm{Cl}_{2} \mathrm{PPh}(57 \mu \mathrm{L}, 0.42$ 
mmol) was added, the reaction mixture was allowed to reach room temperature and stirred for 22 $\mathrm{h}$. The reaction solvent was removed under vacuum and the crude reaction mixture was directly purified by column chromatography using hexane/ $\mathrm{Et}_{3} \mathrm{~N}(96: 4)$ as elution solvent. Compound 11 was obtained as a white solid (38 mg, 35\%), mp: 190-192 $\left.{ }^{\circ} \mathrm{C} .1 \mathrm{H} \mathrm{NMR} \mathrm{(300} \mathrm{MHz}, \mathrm{CDCl}_{3}\right) \delta$ : 7.66-7.60 (m, 2H), 7.41-7.40 (m, 3H), $4.55(\mathrm{~d}, J=9.0,1 \mathrm{H}), 3.86(\mathrm{~d}, J=9.0,1 \mathrm{H}), 1.84(\mathrm{~s}, 3 \mathrm{H})$, $1.57(\mathrm{~s}, 3 \mathrm{H}), 1.56(\mathrm{~s}, 3 \mathrm{H}), 1.55(\mathrm{~s}, 3 \mathrm{H}), 1.46(\mathrm{~s}, 3 \mathrm{H}), 1.33(\mathrm{~s}, 3 \mathrm{H}) .{ }^{13} \mathrm{C} \mathrm{NMR}\left(75 \mathrm{MHz}, \mathrm{CDCl}_{3}\right) \delta$ : $141.0\left(\mathrm{~d}, J^{\mathrm{c}-\mathrm{p}}=6.8\right), 130.5,129.7\left(\mathrm{~d}, J^{\mathrm{c}-\mathrm{p}}=23.6\right), 128.2\left(\mathrm{~d}, J^{\mathrm{c}-\mathrm{p}}=7.5\right), 109.0,82.4\left(\mathrm{~d}, J^{\mathrm{c}-\mathrm{p}}=3.8\right)$, $81.8\left(\mathrm{~d}, J^{\mathrm{c}-\mathrm{p}}=22.5\right), 76.3\left(\mathrm{~d}, J^{\mathrm{c}-\mathrm{p}}=3.8\right), 76.2\left(\mathrm{~d}, J^{\mathrm{c}-\mathrm{p}}=4.5\right), 33.6\left(\mathrm{~d}, J^{\mathrm{c}-\mathrm{p}}=13.5\right), 30.2\left(\mathrm{~d}, J^{\mathrm{c}-\mathrm{p}}=2.3\right)$, $29.2\left(\mathrm{~d}, J^{\mathrm{c}-\mathrm{p}}=3.0\right), 23.3,20.1\left(\mathrm{~d}, J^{\mathrm{c}-\mathrm{p}}=9.0\right) .{ }^{31} \mathrm{P} \mathrm{NMR}\left(121 \mathrm{MHz}, \mathrm{CDCl}_{3}\right) . \delta: 146,38$. HRMS (ESI) calcd for $\mathrm{C}_{17} \mathrm{H}_{25} \mathrm{O}_{5} \mathrm{PNa}\left([\mathrm{M}+\mathrm{Na}]^{+}\right)$: 363.1337. Found: 363.1332

Synthesis of ligand (10). A flame and vacuum dried $25 \mathrm{~mL}$ Schlenk flask equipped with a rubber septum and magnetic stirrer was cooled in an ice bath and $\mathbf{5}(240 \mathrm{mg}, 0.56 \mathrm{mmol})$ and 8.0 $\mathrm{mL}$ of $\mathrm{CH}_{2} \mathrm{Cl}_{2}$ were added under inert atmosphere of nitrogen. $\mathrm{Et}_{3} \mathrm{~N}$ (800 $\mu \mathrm{L}, 5.72 \mathrm{mmol}$ ) was slowly added and the reaction mixture was stirred for $10 \mathrm{~min}$ at $0{ }^{\circ} \mathrm{C}$. The reaction was allowed to reach room temperature and stirred for further $10 \mathrm{~min}$. After cooling again to $0{ }^{\circ} \mathrm{C}$ neat $\mathrm{Cl}_{2} \mathrm{PPh}$ (196 $\mu \mathrm{L}, 1.44 \mathrm{mmol}$ ) was added, the reaction mixture was allowed to reach room temperature and stirred for $22 \mathrm{~h}$. The reaction solvent was removed under vacuum and the crude reaction mixture was directly purified by column chromatography using hexane/ $\mathrm{Et}_{3} \mathrm{~N}(96: 4)$ as elution solvent. Compound 12 was obtained as a white solid (166 mg, 46\%), mp: 104-106 ${ }^{\circ} \mathrm{C} .{ }^{1} \mathrm{H}$ NMR $\left(300 \mathrm{MHz}, \mathrm{CDCl}_{3}\right) \delta: 7.81-7.74(\mathrm{~m}, 4 \mathrm{H}), 7.56-7.50(\mathrm{~m}, 2 \mathrm{H}), 7.46-7.40(\mathrm{~m}, 4 \mathrm{H}), 4.85(\mathrm{~d}, J=9.0$, $2 \mathrm{H}), 4.12(\mathrm{~d}, J=9.0,2 \mathrm{H}), 1.87(\mathrm{~s}, 8 \mathrm{H}), 1.71(\mathrm{~s}, 6 \mathrm{H}), 1.70(\mathrm{~s}, 6 \mathrm{H}), 1.49(\mathrm{~s}, 6 \mathrm{H}), 1.40(\mathrm{~s}, 6 \mathrm{H}) .{ }^{13} \mathrm{C}$ NMR (75 MHz, $\left.\mathrm{CDCl}_{3}\right) \delta: 141.2\left(\mathrm{~d}, J^{\mathrm{c}-\mathrm{p}}=7.5\right), 130.4,129.7\left(\mathrm{~d}, J^{\mathrm{c}-\mathrm{p}}=23.3\right), 128.1\left(\mathrm{~d}, J^{\mathrm{c}-\mathrm{p}}=6.8\right)$, $109.6,82.7\left(\mathrm{~d}, J^{\mathrm{c}-\mathrm{p}}=4.5\right), 82.1\left(\mathrm{~d}, J^{\mathrm{c}-\mathrm{p}}=21.2\right), 76.3\left(\mathrm{~d}, J^{\mathrm{c}-\mathrm{p}}=3.4\right), 76.2\left(\mathrm{~d}, J^{\mathrm{c}-\mathrm{p}}=5.2\right), 30.2\left(\mathrm{~d}, J^{\mathrm{c}-\mathrm{p}}=\right.$ 2.3), $29.2\left(\mathrm{~d}, J^{\mathrm{c}-\mathrm{p}}=2.3\right), 27.3\left(\mathrm{~d}, J^{\mathrm{c}-\mathrm{p}}=13.4\right), 23.4,20.1\left(\mathrm{~d}, J^{\mathrm{c}-\mathrm{p}}=9.8\right),{ }^{31} \mathrm{P} \mathrm{NMR}(121 \mathrm{MHz}$, $\left.\mathrm{CDCl}_{3}\right)$. $\delta$ : 139.30. HRMS (ESI) calcd for $\mathrm{C}_{34} \mathrm{H}_{46} \mathrm{O}_{8} \mathrm{P}_{2} \mathrm{H}\left([\mathrm{M}+\mathrm{H}]^{+}\right)$: 645.2746. Found: 645.2719

\section{Procedure for the conjugate additions}

In a flame and vacuum dried $5 \mathrm{~mL}$ Schlenk flask equipped with a magnetic stirrer and a rubber septum were added $\mathrm{Cu}(\mathrm{OTf})_{2}(1.81 \mathrm{mg}, 0.5 \mathrm{~mol} \%)$, the solvent $(2 \mathrm{~mL})$ and the chiral ligand (1 $\mathrm{mol} \%$ ). The mixture was stirred for $90 \mathrm{~min}$ at room temperature. The reaction flask was cooled to the required temperature and $\mathrm{Et}_{2} \mathrm{Zn}(1.2 \mathrm{mmol}, 1.2 \mathrm{~mL}$ from $1 \mathrm{M}$ solution in heptane $)$ was added with a syringe. The enone $(1 \mathrm{mmol})$ was added neat to the reaction mixture and after stirring for the indicated times and temperatures the reactions were allowed to reach room temperature. Saturated $\mathrm{NH}_{4} \mathrm{Cl}(10 \mathrm{~mL})$ was added and the reaction was extracted three times with $\mathrm{CH}_{2} \mathrm{Cl}_{2}$ (1.5 mL each). The combined organic phases were dried $\left(\mathrm{MgSO}_{4}\right)$ and the solvent removed under reduced pressure. Purification of the addition product was performed by column chromatography using hexane/Et ${ }_{2} \mathrm{O}$ mixtures.

3-Ethyl-cyclohexanone (12). The product was identified by comparison with a racemic authentic sample. Enantiomer separation was achieved with the column indicated before and the 
following chromatographic conditions: injector: detector: $200{ }^{\circ} \mathrm{C}$. Temperature program: $40{ }^{\circ} \mathrm{C}(3$ $\mathrm{min}$ ), $-5^{\circ} \mathrm{C} / \mathrm{min}-110^{\circ} \mathrm{C}$. Flow: $0.50 \mathrm{~mL} / \mathrm{min}$. Major enantiomer: $28.51 \mathrm{~min}$. Minor enantiomer: $29.13 \mathrm{~min}$.

3-Ethyl-cyclopentanone (14). The product was identified by comparison with a racemic authentic sample. Enantiomer separation was achieved with the column indicated before and the following chromatographic conditions: injector: $150^{\circ} \mathrm{C}$, detector: $200^{\circ} \mathrm{C}$. Temperature program: $40{ }^{\circ} \mathrm{C}$ (1 min)-5 ${ }^{\circ} \mathrm{C} / \mathrm{min}-70{ }^{\circ} \mathrm{C}$. Flow: $1 \mathrm{~mL} / \mathrm{min}$. Major enantiomer: $66.96 \mathrm{~min}$. Minor enantiomer: $68.05 \mathrm{~min}$.

4-Phenylhexan-2-one (16a). The product was identified by comparison with a racemic authentic sample. Enantiomer separation was achieved with the column indicated before and the following chromatographic conditions: injector: $200{ }^{\circ} \mathrm{C}$, detector: $250{ }^{\circ} \mathrm{C}$. Temperature program: $40{ }^{\circ} \mathrm{C}(1$ $\mathrm{min}$ ), $-5^{\circ} \mathrm{C} / \mathrm{min}-135^{\circ} \mathrm{C}$. Flow: $0.7 \mathrm{~mL} / \mathrm{min}$. Major enantiomer: $32.66 \mathrm{~min}$. Minor enantiomer: $32.95 \mathrm{~min}$.

4-(4-Methoxyphenyl)hexan-2-one (16b). The product was identified by comparison with a racemic authentic sample. Enantiomer separation was achieved with the column indicated before and the following chromatographic conditions: injector:detector: $250{ }^{\circ} \mathrm{C}$. Temperature program: $40{ }^{\circ} \mathrm{C}(3 \mathrm{~min}),-5^{\circ} \mathrm{C} / \mathrm{min}-140{ }^{\circ} \mathrm{C}(90 \mathrm{~min})$. Flow: $2 \mathrm{~mL} / \mathrm{min}$. Major enantiomer: $46.00 \mathrm{~min}$. Minor enantiomer: $46.50 \mathrm{~min}$.

\section{Acknowledgements}

This work was supported by the Agencia Nacional de Promoción Científica y Tecnológica (ANPCyT), the Consejo Nacional de Investigaciones Científicas y Técnicas (CONICET) and by Universidad Nacional del Litoral. J.P.P. deeply acknowledges the receipt of a fellowship from CONICET.

\section{References and Notes}

1. (a) Diéguez, M.; Pàmies, O.; Ruiz, A.; Díaz, Y.; Castillón, S.; Claver, C. Coord. Chem. Rev. 2004, 248, 2165. (b) Castillón, S.; Claver, C.; Díaz, Y. Chem. Soc. Rev. 2005, 34, 702. (c) Diéguez, M.; Pàmies, O.; Claver, C. Chem. Rev. 2004, 104, 3189.

2. (a) Feringa, B. L. Acc. Chem. Res. 2000, 33, 346. (b) Harutyunyan, S. R.; den Hartog, T.; Geurts, K.; Minnaard, A. J.; Feringa, B. L.Chem. Rev. 2008, 108, 2824. (c) Minaard, A. J.; Feringa, B. L. Lefort, L.; de Vries, J. G. Acc. Chem. Res. 2007, 40 1267. (d) Johnson, N. B.; Lennon, I. C.; Moran, P. H.; Ramsdem, J. A. Acc. Chem. Res. 2007, 40, 1291.

3. (a) Seebach, D.; Beck, A. K.; Heckel, A. Angew. Chem. Int. Ed. 2001, 40, 92. (b) Pellissier, H. Tetrahedron 2008, 64, 10279. 
4. (a) Alexakis, A.; Vastra, J.; Burton, J.; Benhaim, C.; Mangeney, P. Tetrahedron Lett. 1998, 39, 7869. (b) Alexakis, A.; Benhaim, C.; Rosset, S.; Human, M. J. Am. Chem. Soc. 2002, 124, 5262. (c) For detailed account on enantioselective copper-catalyzed conjugate addition and allylic substitution see: Alexakis, A.; Bäckvall, J. E.; Krause, N.; Pàmies, O.; Diéguez, M. Chem. Rev. 2008, 108, 2796

5. (a) Alexakis, A.; Vastra, J.; Burton, J.; Benhaim, C.; Mangeney, P.; Tetrahedron Lett. 1998, 39, 7869. (b) Alexakis, A.; Burton, J.; Vastra, J.; Benhaim, C.; Fourniuox, X.; van den Heuvel, A.; Leveque, J. M.; Maze, M.; Rosset, S.; Eur. J. Org. Chem. 2000, 4011.

6. (a) Alexakis, A.; Benhaim, C. Org. Lett. 2000, 2, 2579. (b) Polet, D.; Alexakis, A.; Tetrahedron Lett. 2005, 46, 1529

7. Bee, C.; Han, S. B.; Hassan, A.; Lida, H.; Krische, M. J. J. Am. Chem. Soc. 2008, 130, 2746.

8. (a) Seebach, D.; Hayakawa, M.; Sakaki, J.-I.; Schweizer, W. B. Tetrahedron 1993, 49, 1711.

(b) Handrosch, C.; Heinemann, F. W.; Kisch, H. Z. Naturforsh B 1999, 54, 1015.

9. Shao, M.-Y.; Gau, H.-M. Organometallics 1998, 17, 4822.

10. (a) Tanaka, K.; Nagashiro, R.; Urbanczyk-Lipkowska, Z. Org. Lett. 2001, 3, 1567. (b) Tanaka, K.; Fujiwara, T.; Urbanczyk-Lipkowska, Z. Org. Lett. 2002, 4, 3255. (c) Belokon, Y. N.; Gugkaeva, Z. T.; Malee, V. I.; Moskalenko, M. A.; North, M.; Tsaloev, A. T. Tetrahedron:Asymmetry 2010, 21, 1793.

11. Legrand, S.; Luukinen, H.; Isaksson, R.; Kilpeläinen, I.; Lindström, M.; Nicholls, I. A.; Unelius, C. R. Tetrahedron:Asymmetry 2005, 16, 635.

12. (a) Ito, Y.N.; Ariza, X; Beck, A. K.; Bohac, A.; Ganter, C.; Gawley, R. E.; Kuehnle, F. N. M.; Tuleja, J.; Wang, Y. M.; Seebach, D. Helv. Chim. Acta 1994, 77, 2071. (b) Seebach, D.; Beck, A. K.; Imwinkelried, R.; Roggo, S.; Wonnacott, A. Helv. Chim. Acta 1987, 70, 954.

13. Greeves, N.; N.; Pease, J. E.; Tetrahedron Lett. 1996, 37, 2675

14. For recent review on phosphites chiral ligands is asymmetric catalysis see: van Leewen, P. W. N. M.; Kamer, P. C.; Claver, C.; Pàmies, O.; Diéguez, M. Chem. Rev. 2011, 111, 2077.

15. (a) Matteson, D. S.; Beedle, E. C.; Kandil, A. A. J. Org. Chem. 1987, 52, 1987. (b) Carmack, M.; Kelley, C. J. J. Org. Chem. 1968, 33, 2171. (c) Toda, F.; Tanaka, K. Tetrahedron Lett. 1988, 29, 551.

16. Greene, N.; Kee, T.P. Synth. Commun. 1993, 23, 1651.

17. (a) Seebach, D.; Hayakawa, M.; Sakaki, J.; Schweizer, B. Tetrahedron 1993, 49, 1711. (b) Sakaki, J.; Schweizer, W. B.; Seebach, D. Helv. Chim. Acta 1993, 76, 2654. (c) Mewald, M.; Weickgenannt, A.; Frölich, R.; Oestreich, M. Tetrahedron:Asymmetry 2010, 21, 1232.

18. Alexakis, A.; Benhaim, C. Eur. J. Org. Chem. 2002, 3221.

19. Drake, N. L.; Allen Jr, O. Org. Synth. 1923, 3, 17. 